\title{
Dual-Use Technology Jepang dan Kepentingan Keamanan Nasional Amerika Serikat
}

\author{
Rizky Roza \\ Jurusan IImu Hubungan Internasional, Universitas Indonesia \\ Depok, Jawa Barat, 16424 \\ Email: rizky_roz@yahoo.com
}

\begin{abstract}
The dynamic relations between Japan and the United States are interesting to be observed due to frequently happen in "non-conventional ". Japan and America are two countries leading in the development of high technology, including military technology capabilities. The competition, both in the development of military technology often brings a unique and surprising relationship pattern. This paper shows that Japan continues to develop military technology that affects perception and capability of the country in the international political stage. On the other hand, the Japanese military technology development has given rise to responses from a number of countries in the region, as well as from major countries like USA. This paper shows that the achievement and the use of military technology will determine the future of the country's diplomacy with major countries in the world, especially the United States.

Keywords: national security, Post-Cold War, Self Defense Force, Security Assistance Program.

\section{Abstrak}

Dinamika hubungan Jepang dan Amerika Serikat menarik diamati karena sering berlangsung secara "non-konvensional". Jepang dan Amerika merupakan dua negara terdepan dalam pengembangan teknologi tinggi, termasuk kemampuan teknologi militer. Kompetisi keduanya dalam pengembangan teknologi militer sering membawa pola relasi yang unik dan mengejutkan.. Tulisan ini menunjukkan bahwa Jepang terus berupaya mengembangkan teknologi militer yang mempengaruhi persepsi serta kapabilitas negara tersebut di panggung politik internasional di satu sisi. Di sisi lain, pengembangan teknologi militer Jepang telah melahirkan respon-respon dari sejumlah negara kawasan, maupun dari negara besar seperti Amerika. Tulisan ini menunjukkan bahwa pencapaian dan penggunaan teknologi militer akan menentukan masa depan diplomasi negara tersebut dengan negara-negara besar di dunia, khususnya Amerika Serikat.

Kata kunci: keamanan nasional, Pasca Perang Dingin, self defence force, security assistance program-,
\end{abstract}

\section{PENDAHULUAN}

Perkembangan teknologi merupakan faktor pemicu terjadinya perubahan instrumen, pemikiran, dan institusi perang. ${ }^{1}$ Penemuan bubuk mesiu pada abad ke-16, penerapan revolusi industri terhadap perang pada awal abad ke-19, serta penggunaan mikroelektronik, teknologi stealth, dan penerapan revolusi informasi sejak 1970-an, merupakan wujud pengaruh besar yang ditimbulkan setiap inovasi teknologi terhadap berbagai dimensi perang. Perkembangan teknologi mendorong terjadinya transformasi kekuatan militer dan memunculkan konsep-konsep operasional baru. Perkembangan teknologi tidak hanya menghasilkan instrumen perang baru, tetapi juga menuntut akademisi dan praktisi militer untuk memikirkan keunggulan dan ancaman baru yang dimunculkan oleh inovasi tersebut, bagaimana inovasi tersebut dimanfaatkan, serta bagaimana konsep operasionalnya. ${ }^{2}$

Keunggulan teknologi militer seringkali menentukan nasib sebuah bangsa ketika berhadapan 
dengan kekuatan militer negara lain. Sehingga, menjadi kepentingan setiap bangsa untuk terus meningkatkan keunggulan teknologi militernya, dan jika dimungkinkan, untuk menghambat perkembangan teknologi militer negara lain yang dapat mengancam kepentingan keamanan nasionalnya.

Pada Juli 2007 diberitakan bahwa pemerintah Jepang berencana untuk mengembangkan sendiri sebuah prototipe jet tempur mutakhir. Proyek ini akan menjadi jet tempur pertama yang dibangun oleh Jepang sejak 1970an. Jet tempur ini akan dibangun menggunakan teknologi yang diperoleh melalui kerjasama yang telah dibangun AS-Jepang sebelumnya, yaitu kesepakatan kedua negara untuk memproduksi bersama jet tempur F-2. Kerjasama tersebut disepakati pada 1980an dan akan berakhir pada 2011. Rencana pengembangan prototipe ini merupakan respon terhadap penolakan AS untuk menjual F-22 Raptor. Jepang berharap bisa membeli F-22 Raptor untuk menggantikan jet tempur F-4 yang telah beroperasi sejak 1973. Namun, hingga saat ini proposal Jepang terus ditolak kongres AS. Kongres melarang penjualan atau pemberian lisensi F-22 Raptor kepada negara lain demi menjaga kerahasiaan teknologi. Rencanan pengembangan prototipe ini belum diarahkan untuk membangun sendiri jet temput yang sesungguhnya, tetapi dimaksudkan agar AS bersedia mencabut larangan penjualan F-22 Raptor dan menekan harga jualnya yang mencapai US\$130 juta. ${ }^{3}$

Kondisi tersebut menimbulkan beberapa pertanyaan, antara lain: Mengapa kongres AS menolak penjualan F-22 kepada Jepang? Bukankah dengan teknologi yang serupa justru akan mempermudah kerjasama operasi antara kedua negara dan memperkuat aliansi mereka? Bukankah AS juga menginginkan agar Jepang memiliki kekuatan militer yang lebih mandiri sehingga mengurangi beban AS dalam menjaga keamanan dan stabilitas internasional, khususnya kawasan Asia Timur? Apakah AS menganggap Jepang sebagai ancaman sehingga peningkatan kekuatan militer Jepang akan membahayakan kepentingan AS? Atau AS tidak mempercayai Jepang untuk menjaga kerahasiaan teknologi yang dimiliki F-22 Raptor?

Penolakan AS atas permohonan Jepang untuk membeli F-22 Raptor dapat dijelaskan dengan menguraikan setidaknya empat hal: pertama, pengalaman kerjasama teknologi militer antara kedua negara pada masa lalu (masa Perang Dingin); kedua, rezim pengendalian ekspor multilateral yang melibatkan kedua negara; ketiga, kepentingan keamanan nasional AS; dan keempat, proliferasi dualuse technology Jepang Pasca Perang Dingin..

\section{PEMBAHASAN}

KERJASAMA TEKNOLOGI AS-JEPANG MASA PERANG DINGIN

Kapabilitas teknologi dan perindustrian yang dimiliki Jepang saat ini merupakan hasil dari pemanfaatan teknologi militer yang diperolehnya dari Amerika sejak 1960-an. Sejak awal dibentuknya aliansi dengan Jepang, AS berupaya untuk mendorong pertumbuhan ekonomi Jepang agar Jepang tidak menjadi beban jangka panjang bagi AS. Untuk merangsang industri elektronik Jepang, AS memberikan lisensi produksi radio, yang kemudian berhasil berkembang menjadi industri televisi. Jepang juga berhasil menyerap teknologi militer melalui lisensi produksi persenjataan AS, yang dilandasi the Mutual Defence Assistance Agreement, 1954.

AS memberikan bantuan persenjataan dan pelatihan bagi Self-Defence Forces Jepang. Melalui kerangka Military Assistance Program (MAP), AS memberikan bantuan perlengkapan persenjataan, kapal perang, dan pesawat tempur, serta melatih teknisi Jepang agar mampu melakukan perawatan dan perbaikan sistem persenjataan AS di Jepang. Kemudian, pada 1960an MAP berakhir sehingga untuk membangun sistem pertahanannya, Jepang harus membeli dari AS. Namun co-production perlengkapan AS mulai dilakukan, dan Jepang mulai mampu mengembangkan perlengkapan dasar pertahanan. Pada 1970an, pembelian dan co-production semakin luas, penelitian dan pengembangan semakin meningkat, dan Jepang sudah mampu melakukan produksi sendiri. Kemudian pada 1980an, program 
pengembangan yang dilakukan Jepang semakin banyak, dan co-production sudah berkaitan dengan bagian penting dari sistem pertahanan AS. Nilai pembelian perlengkapan pertahanan oleh Jepang dan co-production dengan AS melampaui sekutu-sekutu AS lainnya.

Transfer teknologi yang diperoleh Jepang dari AS pada masa itu tidak hanya bermanfaat bagi industri militer tetapi juga untuk industri komersil. Dengan berbekal teknologi militer AS, Jepang melakukan pengembangan sehingga mendorong tumbuhnya industri komersil Jepang, yang pada akhirnya menghasilkan pertumbuhan ekonomi. Nilai perdagangan AS-Jepang selama tahun 1960an menguntungkan AS, tetapi pada 1970an nilai perdagangan antar kedua negara mulai lebih menguntungkan Jepang.

Sejak 1980-an, Jepang telah menjadi salah satu negara yang memiliki perindustrian yang didukung teknologi maju. Produk-produk Jepang bahkan mampu menjadi kompetitor Amerika di pasar dunia, misalnya dalam industri semikonduktor. Pada 1987, Jepang mengungguli AS dalam 12 dari 24 kategori teknologi semikonduktor, menguasi $50 \%$ pasar dunia yang pada satu dekade sebelumnya hanya $30 \%{ }^{4}$

Pertumbuhan ekonomi dan perkembangan SDF merupakan bagian dari keberhasilan Jepang menyerap teknologi AS, yang pada 1980an perkembangan teknologi Jepang justru menimbulkan friksi antara kedua negara. ${ }^{5}$ Kemampuan Jepang untuk menyerap teknologi militer AS dan melakukan spin-off ${ }^{6}$ ternyata berdampak strategis dan ekonomis bagi AS. Pada satu sisi, transfer teknologi memiliki peran besar dalam meningkatkan kemampuan industri, pertumbuhan ekonomi Jepang, serta peningkatan kekuatan SDF. Namun di sisi lain, perkembangan ini tidak hanya mengurangi beban AS tetapi juga dapat mengancam perindustrian AS serta kepentingan keamanan nasionalnya.

Kekhawatiran AS atas perkembangan kapabilitas teknolgi Jepang meningkat ketika Jepang mengajukan proyek FSX. Proyek FSX merupakan proyek pertama kerjasama produksi persenjataan AS-Jepang sejak berakhirnya PD II, yang menjadi titik balik bagi Japan
Defence Agency (JDA). FSX dimaksudkan untuk menggantikan pesawat tempur F-1 Jepang-pesawat buatan Jepang pertama yang dibuat pada 1975-yang sudah kuno. FSX merupakan modifikasi dari F-16 buatan Lockheed.

Pada awalnya Jepang berencana untuk memproduksi sendiri secara keseluruhan dengan lisensi Amerika. Sedangkan AS menuntut keterlibatan industri militer AS dalam proyek FSX. AS menolak proposal Jepang untuk menjalankan sendiri proyek tersebut. Peningkatan kapabilitas teknologi Jepang dan kenyataan bahwa Jepang telah menjadi salah satu kekuatan ekonomi dunia mendorong AS untuk meninjau kembali security assistance program-nya. AS menginginkan Jepang lebih aktif dalam kerjasama keamanan kedua negara. AS mendorong Jepang untuk melakukan kerjasama teknologi pertahanan dimana terjadi transfer teknologi dua arah, termasuk dalam proyek FSX.

Sebelumnya, transfer teknologi militer hanya berlangsung satu arah, yaitu dari AS kepada Jepang. Hal ini dikarenakan adanya kebijakan pemerintah Jepang yang melarang ekspor persenjataan dan teknologi militer, yaitu The Three Principles on Arms Exports. Kebijakan yang dikeluarkan pada tahun 1967 oleh Perdana Menteri Eisaku Sato ini melarang Jepang mengekspor senjata kepada negara-negara: 1)blok komunis, 2)yang diembargo senjata oleh PBB, 3)yang terlibat atau mungkin terlibat dalam konflik internasional. Prinsip ini dipertegas pada 1976 oleh Perdana Menteri Takeo Miki di dalam the Policy Guideline on Arms Export yang menyatakan larangan ekspor senjata ke wilayah mana pun di dunia tidak terbatas pada yang ditetapkan oleh the Three Principles. Pada 1983, atas permintaan AS, pemerintah Jepang mengeluarkan kebijakan yang mengizinkan transfer teknologi militer kepada AS sebagai pengecualian the Three Principles. Pengecualian ini diberikan berdasarkan the Mutual Defense Assistance Agreement dan the 1983 Exchange of Notes yang berkaitan dengan transfer teknologi militer.

Berlandaskan pada the 1983 Exchange of Notes dan melalui perdebatan panjang mengenai proyek FSX, 
pada 1989 kedua negara sepakat menetapkan Mitsubishi Heavy Industry sebagai kontraktor utama, dengan Lockheed (AS), Fuji Heavy Industry (Jepang) dan Kawasaki Heavy Industry (Jepang) sebagai subkontraktor. Lockheed dan sub-kontraktor lainnya akan menjalankan 40 persen produksi sementara MHI mengerjakan sisanya.

Proyek ini tidak hanya menunjukkan peningkatan kemampuan Jepang tetapi kemunculan kompetitor baru bagi industri AS. Perdebatan antara kedua negara terjadi selama negosiasi pelaksanaan proyek FSX. Friksi yang terjadi sejak awal 1980an tersebut menarik perhatian banyak pihak dan juga menimbulkan dampak yang berkepanjangan terhadap hubungan kedua negara. Pihak AS memandang proyek FSX sebagai upaya Jepang untuk menandingi keunggulan teknologinya, sedangkan beberapa pihak di Jepang menilai izin transfer teknologi militer terhadap AS dan friksi yang terjadi selama negosiasi proyek FSX sebagai bentuk pembendungan perkembangan teknologi Jepang oleh AS.

Persoalan lain yang semakin memperburuk hubungan kedua negara berkaitan dengan teknologi militer adalah sejumlah pelanggaran terhadap regulasi COCOM (the Coordinating Committee for Multilateral Export Control) $)^{7}$, terutama insiden Toshiba-Kongsberg. Pelanggaran tersebut antara lain:

- Awal 1970an salah satu perusahaan Jepang, Ishikawajima-Harima Heavy Industry (IHI), menjual sebuah galangan kapal terapung raksasa kepada Soviet, sehingga menuai protes dari Departemen Pertahanan AS karena dianggap dapat memperkuat Armada Pasifik Soviet;

- April 1987, terungkap penjualan baling-baling kapal selam oleh Toshiba Machine Co. kepada Soviet. Teknologi yang dikembangkan Toshiba bersama Kongsberg Vaapenfabrikk (perusahaan Norwegia) menyebabkan kapal selam Soviet yang sebelumnya mengeluarkan suara keras sehingga mudah dilacak, menjadi lebih tenang dan sulit dilacak;

- Awal 1990an juga terungkap pelanggaran dilakukan oleh Japan Aviation Electronics Industry Corporation
(JAE). JAE menjual komponen-komponen F4 Phantom yang diproduksi dibawah lisensi AS kepada Iran, ketika AS sendiri membekukan hubungan dagangnya dengan Iran. Diketahui penjualan dilakukan melalui perusahaan yang berbasis di Florida, Singapura dan Hongkong. ${ }^{8}$

Pelanggaran-pelanggaran tersebut kembali mempertegas bahwa peningkatan kapabilitas teknologi Jepang tidak hanya dapat merugikan AS secara ekonomis, tetapi juga dapat berdampak strategis dan mengancaman kepentingan keamanan nasional AS.

Meskipun Jepang memiliki kebijakan yang melarang ekpor persenjataan dan teknologi militer, dan AS telah memberikan sanksi kepada perusahaan-perusahaan Jepang yang melanggar COCOM, serta Jepang sendiri telah memperketat pengaturan dan pengawasan transfer teknologinya pasca insiden di atas, kemungkinan terjadinya insiden serupa masih ada. Hal ini dikarenakan sulitnya untuk mengatur dan mengawasi arus transfer dual-use technology (DUT).

Teknologi militer yang sebelumnya dikembangkan melalui program khusus yang dibatasi dan didukung sepenuhnya oleh militer, sejak 1970an mulai memanfaatkan teknologi yang dikembangkan oleh industri komerisil/sipil. Teknologi yang dapat dimanfaatkan untuk kepentingan sipil maupun militer kemudian lebih dikenal sebagai Dual-Use Technology (DUT). Yang termasuk dual-use technology yaitu: process technologies that are used in the manufacture of components for civilian and military systems; technologies embodied in products that enhance the performance of military and civilian systems; and know-how or applied knowledge that is necessary for the design, development, and manufacture of military and civilian products. ${ }^{9}$

Setidaknya ada delapan sektor industri sipil yang paling potensial untuk mendukung pengembangan teknologi militer, yaitu: mikroelektronik, komputer, perlengkapan telekomunikasi, tenaga nuklir, bioteknologi, kimia, penerbangan, dan luar angkasa. ${ }^{10}$

Konsekuensi dari nilai 'strategis-militer' dan 'komersil-sipil' yang dikandung DUT adalah 
penyebarannya relatif lebih sulit dikontrol daripada teknologi atau item militer saja. Melalui pengalihan pemanfaatannya, DUT dapat digunakan untuk mengembangkan teknologi persenjataan yang secara strategis berbahaya (strategically dangerous armaments/ $\mathrm{SDA})^{11}$, yang pada akhirnya mungkin saja digunakan untuk mengancaman keamanan nasional negara asal DUT atau negara lain, bahkan dapat mengancam stabilitas dan keamanan regional maupun internasional.

Jika dengan kebijakan-kebijakannya berarti bahwa tidak akan terjadi penyebaran secara luas persenjataan dan teknologi militer Jepang ke pasar persenjataan internasional, masih sangat mungkin terjadi penyebaran DUT Jepang karena kebijakan-kebijakan tersebut tidak dapat diterapkan pada penyebaran teknologi yang sifatnya dapat dimanfaatkan untuk kepentingan sipil (dual-use technology).

\section{REZIM PENGENDALIAN EKSPOR MULTILATERAL}

Mekanisme yang dapat digunakan untuk mengendalikan penyebaran teknologi adalah melalui supply-side export control, baik secara unilateral maupun multilateral. ${ }^{12}$ Tetapi terdapat persoalan dalam menjaga keseimbangan antara tuntutan untuk mengendalikan penyebaran DUT yang dapat dimanfaatkan dalam pengembangan SDA, sementara di sisi lain mendorong penyebaran teknologi demi pertumbuhan ekonomi dan perkembangan teknologi itu sendiri.

Pada tingkat multilateral terdapat sejumlah rezim pengendalian ekspor yang berlaku dan mengatur transfer dual-use technology. Rezim ini menjadi pedoman bagi negara anggotanya dalam menyusun sistem pengendalian ekspor nasional, termasuk AS dan Jepang (Lihat Tabel 1). Rezim tersebut antara lain: The Coordinating Committee for Multilateral Export Control (COCOM), The Zangger Committee, The Nuclear Supplier Group, The Australia Group, The Missile Technology Control Regime, dan Wassenaar Arrangement.

COCOM dibentuk pada tahun 1949 dan dibubarkan pada 31 Maret 1994. COCOM beranggotakan seluruh anggota NATO, terkecuali
Islandia, ditambah Jepang dan Australia. COCOM dibentuk untuk membatasi ekspor item-item strategis pada Uni-Soviet, negara-negara Eropa Timur, dan RRC. COCOM diarahkan untuk menghambat negaranegara komunis memperoleh item-item strategis yang dapat memberikan kontribusi langsung pada kemampuan militer mereka. COCOM merupakan forum informal dimana setiap keputusannya tidak mengikat secara legal (no legally binding status).

The Zangger Committee ${ }^{13}$ dibentuk untuk merespon berlakunya the Nuclear Non-Proliferation Treaty (NPT) sejak 5 Maret 1970. The ZC merupakan kelompok informal negara-negara partisipan NPT untuk menginterpretasikan tanggung jawab mereka terhadap Artikel III.2 NPT karena tidak terdapat penjelasan spesifik atas artikel tersebut. ${ }^{14}$ Melalui interpretasi dan implementasi artikel III.2, the ZC membantu pencegahan pengalihan ekspor nuklir dengan tujuan damai menjadi senjata nuklir atau alat peledak nuklir lainnya.

The Nuclear Suppliers Group (the NSG) merupakan suatu kelompok negara-negara supplier nuklir yang berusaha untuk memberi kontribusi bagi nonproliferasi senjata nuklir melalui implementasi suatu pedoman (guidelines) yang mengatur ekspor bahanbahan nuklir dan bahan lain yang berkaitan dengan nuklir. The NSG dimaksudkan untuk melibatkan negara-negara supplier nuklir tetapi bukan bagian NPT seperti Perancis. ${ }^{15}$

The Australia Group (1985) dibentuk untuk merespon temuan bahwa terjadi pelanggaran atas Protokol Jenewa 1925 melalui penggunaan senjata kimia terhadap Iran dalam Perang Irak-Iran (19801988). Bukti-bukti yang menunjukkan bahwa Irak memperoleh sebagian besar material untuk program senjata kimianya dari industri kimia internasional melalui jalur perdagangan yang dibenarkan (legitimate trade channels), turut melatarbelakangi pembentukan the AG. Tujuan dasar the AG adalah to use licensing measures to ensure that exports of certain chemicals, biological agents, and dual-use chemical and biological manufacturing facilities and equipment, do not contribute to the spread of $\mathrm{CBW}{ }^{16}$ The AG memberikan kontribusi penting 
untuk mencapai tujuan-tujuan Chemical Weapons Convention (CWC, 1993) dan Biological and Toxin Weapons Convention (BWC, 1972). ${ }^{17}$

The MTCR dibentuk (1987) oleh negara-negara G-7 (Kanada, Perancis, Jerman, Italia, Jepang, Inggris dan AS) karena terjadi peningkatan proliferasi senjata pemusnah masal, seperti senjata nuklir, kimia dan biologi. Tujuan pembentukan the MTCR adalah untuk mengendalikan transfer misil dan teknologi yang berkaitan, yang dapat digunakan untuk meluncurkan senjata pemusnah masal-senjata nuklir, biologi dan kimia (NBC weapons). ${ }^{18}$

The Wassenaar Arrangement dibentuk pada 1996 oleh negara-negara ex-COCOM beserta sejumlah negara lainnya antara lain: Rusia, Republik Ceko, Hungaria, Polandia, Republik Slovakia, Argentina, Republik Korea, Rumania, Bulgaria, Ukraina, sebagai respon atas pembubaran COCOM. The WA dibentuk untuk memberi kontribusi bagi keamanan dan stabilitas regional dan internasional dengan cara mengedepankan transparansi dan tanggung jawab yang lebih besar dalam melakukan transfer senjata konvensional dan barang dan teknologi dual-use sehingga dapat mencegah meningkatnya destabilisasi. The WA tidak diarahkan pada negara atau kelompok negara tertentu, dan tidak untuk menghambat keuntungan transaksi sipil. The WA juga tidak untuk mencampuri hak setiap negara dalam mencari cara mempertahankan diri, sesuai dengan Artikel 51 Piagam PBB.

Rezim-rezim pengendalian ekspor tersebut mengatur proliferasi dual-use technology terutama yang berkaitan dengan senjata pemusnah masal (senjata nuklir, kimia, dan biologi), sistem peluncur senjata pemusnah masal (teknologi misil dan roket), serta teknologi senjata konvensional modern. Meskipun COCOM dibubarkan, masih terdapat rezim yang mengatur penyebaran item-item tertentu yang sebelumnya diatur oleh COCOM. Berbeda dengan COCOM yang diarahkan pada negara-negara blok Timur, rezim-rezim lainnya tidak diarahkan kepada negara tertentu, bukan untuk mewakili kepentingan nasional satu atau sekelompok negara, melainkan ditujukan untuk menjaga perdamaian dan stabilitas internasional. Tidak terdapat pula rezim yang ketetapannya mengikat secara legal. Implementasi ketetapan rezim sangat tergantung pada kebijakan nasional masing-masing negara.

Upaya pencapaian tujuan rezim-rezim ini juga menghadapi persoalan munculnya supplier baru atas pengetahuan dan teknologi yang berkaitan dengan pengembangan dan produksi senjata nuklir, kimia, dan biologi, yaitu terdapatnya jaringan ilmuwan (network of knowledgeable individuals). Perhatian atas persoalan ini meningkat ketika terungkap pada Februari 2004 bahwa sejak 1992 jaringan ilmuwan yang dipimpin oleh ahli nuklir Pakistan, Abdul Qadeer Khan, menyusun dan melakukan kordinasi suplay material nuklir, pengetahuan (know-how) dan perlengkapan kepada Korea Utara, Iran dan Libya. Jaringan Khan juga berkolaborasi dengan partisipan yang berada dan beroperasi di negara anggota NSG.

Rezim-rezim pengendalian ekspor multilateral yang ada sangat lemah secara struktural dan implementasi. Rezim-rezim di atas tidak mengikat secara legal dan tidak memiliki mekanisme verifikasi kepatuhan partisipan. Dalam kondisi seperti ini tujuan rezim akan sangat sulit dicapai. Pertimbangan nilai komersil dan strategis dari setiap item yang dikontrol akan sangat mempengaruhi kepatuhan setiap negara terhadap rezim. Tanpa enforcement mechanism, setiap partisipan akan dengan mudah melanggar kesepakatan. Persoalan ini merupakan persoalan mendasar yang selalu menghambat tercapainya tujuan kerjasama dan institusi internasional. Rezim-rezim pengendalian ekspor yang ada tidak dapat mengatasi persoalan ini.

\section{KEPENTINGAN KEAMANAN NASIONAL AS}

Sejak awal pendirian, AS telah menetapkan tujuan dasarnya, yaitu: "to maintain security, political freedom, and independence of the United States, with its values, institutions, and territory intact; to protect the lives and personal savety of Americans, both at home and abroad; and to provide for the well-being and prosperity of the nation and its people". Untuk mencapai tujuan dasar tersebut, setiap periode pemerintahan menetapkan prioritas dan menyusun strategi nasional. Karena itu, kepentingan 
Tabel 1

Partisipan Rezim Pengendalian Ekspor Mulitlateral

\begin{tabular}{|c|c|c|c|c|c|c|}
\hline & $\begin{array}{l}\text { COCOM } \\
(1947-1994)\end{array}$ & $\begin{array}{l}\text { Zangger } \\
\text { Committee } \\
\text { (1974) }\end{array}$ & $\begin{array}{l}\text { NSG } \\
(1978)\end{array}$ & $\begin{array}{l}\text { Australia } \\
\text { Group } \\
(1984)\end{array}$ & $\begin{array}{l}\text { MTCR } \\
(1987)\end{array}$ & $\begin{array}{l}\text { Wassenaar } \\
\text { Arrangement } \\
(1996)\end{array}$ \\
\hline Afrika Selatan & & $\sqrt{ }$ & $\sqrt{ }$ & & $\sqrt{ }$ & \\
\hline AS & $\sqrt{ }$ & $\sqrt{ }$ & $\sqrt{ }$ & $\sqrt{ }$ & $\sqrt{ }$ & $\sqrt{ }$ \\
\hline Argentina & & $\sqrt{ }$ & $\sqrt{ }$ & $\sqrt{ }$ & $\sqrt{ }$ & $\sqrt{ }$ \\
\hline Australia & $\sqrt{ }$ & $\sqrt{ }$ & $\sqrt{ }$ & $\sqrt{ }$ & $\sqrt{ }$ & $\sqrt{ }$ \\
\hline Austria & & $\sqrt{ }$ & $\sqrt{ }$ & $\sqrt{ }$ & $\sqrt{ }$ & $\sqrt{ }$ \\
\hline Belanda & $\sqrt{ }$ & $\sqrt{ }$ & $\sqrt{ }$ & $\sqrt{ }$ & $\sqrt{ }$ & $\sqrt{ }$ \\
\hline Belarus & & & $\sqrt{ }$ & & & \\
\hline Belgia & $\sqrt{ }$ & $\sqrt{ }$ & $\sqrt{ }$ & $\sqrt{ }$ & $\sqrt{ }$ & $\sqrt{ }$ \\
\hline Brazil & & & $\sqrt{ }$ & & $\sqrt{ }$ & \\
\hline Bulgaria & & $\sqrt{ }$ & $\sqrt{ }$ & $\sqrt{ }$ & $\sqrt{ }$ & $\sqrt{ }$ \\
\hline Ceko & & $\sqrt{ }$ & $\sqrt{ }$ & $\sqrt{ }$ & $\sqrt{ }$ & $\sqrt{ }$ \\
\hline China & & $\sqrt{ }$ & $\sqrt{ }$ & & & \\
\hline Cyprus & & & $\sqrt{ }$ & $\sqrt{ }$ & & \\
\hline Denmark & $\sqrt{ }$ & $\sqrt{ }$ & $\sqrt{ }$ & $\sqrt{ }$ & $\sqrt{ }$ & $\sqrt{ }$ \\
\hline Estonia & & & $\sqrt{ }$ & $\sqrt{ }$ & & $\sqrt{ }$ \\
\hline Finlandia & & $\sqrt{ }$ & $\sqrt{ }$ & $\sqrt{ }$ & $\sqrt{ }$ & $\sqrt{ }$ \\
\hline Hungaria & & $\sqrt{ }$ & $\sqrt{ }$ & $\sqrt{ }$ & $\sqrt{ }$ & $\sqrt{ }$ \\
\hline Inggris & $\sqrt{ }$ & $\sqrt{ }$ & $\sqrt{ }$ & $\sqrt{ }$ & $\sqrt{ }$ & $\sqrt{ }$ \\
\hline Irlandia & & $\sqrt{ }$ & $\sqrt{ }$ & $\sqrt{ }$ & $\sqrt{ }$ & $\sqrt{ }$ \\
\hline Islandia & & & & $\sqrt{ }$ & $\sqrt{ }$ & \\
\hline Italia & $\sqrt{ }$ & $\sqrt{ }$ & $\sqrt{ }$ & $\sqrt{ }$ & $\sqrt{ }$ & $\sqrt{ }$ \\
\hline Jepang & $\sqrt{ }$ & $\sqrt{ }$ & $\sqrt{ }$ & $\sqrt{ }$ & $\sqrt{ }$ & $\sqrt{ }$ \\
\hline Jerman & $\sqrt{ }$ & $\sqrt{ }$ & $\sqrt{ }$ & $\sqrt{ }$ & $\sqrt{ }$ & $\sqrt{ }$ \\
\hline Kanada & $\sqrt{ }$ & $\sqrt{ }$ & $\sqrt{ }$ & $\sqrt{ }$ & $\sqrt{ }$ & $\sqrt{ }$ \\
\hline Kazakhstan & & & $\sqrt{ }$ & & & \\
\hline Korea Selatan & & $\sqrt{ }$ & $\sqrt{ }$ & $\sqrt{ }$ & $\sqrt{ }$ & $\sqrt{ }$ \\
\hline Kroasia & & & $\sqrt{ }$ & & & $\sqrt{ }$ \\
\hline Latvia & & & $\sqrt{ }$ & $\sqrt{ }$ & & $\sqrt{ }$ \\
\hline Lithuania & & & $\sqrt{ }$ & $\sqrt{ }$ & & $\sqrt{ }$ \\
\hline Luxembourg & $\sqrt{ }$ & $\sqrt{ }$ & $\sqrt{ }$ & $\sqrt{ }$ & $\sqrt{ }$ & $\sqrt{ }$ \\
\hline Malta & & & $\sqrt{ }$ & $\sqrt{ }$ & & $\sqrt{ }$ \\
\hline Norwegia & $\sqrt{ }$ & $\sqrt{ }$ & $\sqrt{ }$ & $\sqrt{ }$ & $\sqrt{ }$ & $\sqrt{ }$ \\
\hline Perancis & $\sqrt{ }$ & $\sqrt{ }$ & $\sqrt{ }$ & $\sqrt{ }$ & $\sqrt{ }$ & $\sqrt{ }$ \\
\hline Polandia & & $\sqrt{ }$ & $\sqrt{ }$ & $\sqrt{ }$ & $\sqrt{ }$ & $\sqrt{ }$ \\
\hline Portugal & $\sqrt{ }$ & $\sqrt{ }$ & $\sqrt{ }$ & $\sqrt{ }$ & $\sqrt{ }$ & $\sqrt{ }$ \\
\hline Romania & & $\sqrt{ }$ & $\sqrt{ }$ & $\sqrt{ }$ & $\sqrt{ }$ & $\sqrt{ }$ \\
\hline Russia & & $\sqrt{ }$ & $\sqrt{ }$ & & $\sqrt{ }$ & $\sqrt{ }$ \\
\hline Selandia Baru & & & $\sqrt{ }$ & $\sqrt{ }$ & $\sqrt{ }$ & $\sqrt{ }$ \\
\hline Slovakia & & $\sqrt{ }$ & $\sqrt{ }$ & $\sqrt{ }$ & & $\sqrt{ }$ \\
\hline Slovenia & & $\sqrt{ }$ & $\sqrt{ }$ & $\sqrt{ }$ & & $\sqrt{ }$ \\
\hline Spanyol & $\sqrt{ }$ & $\sqrt{ }$ & $\sqrt{ }$ & $\sqrt{ }$ & $\sqrt{ }$ & $\sqrt{ }$ \\
\hline Swedia & & $\sqrt{ }$ & $\sqrt{ }$ & $\sqrt{ }$ & $\sqrt{ }$ & $\sqrt{ }$ \\
\hline Switzerland & & $\sqrt{ }$ & $\sqrt{ }$ & $\sqrt{ }$ & $\sqrt{ }$ & $\sqrt{ }$ \\
\hline Turki & $\sqrt{ }$ & $\sqrt{ }$ & $\sqrt{ }$ & $\sqrt{ }$ & $\sqrt{ }$ & $\sqrt{ }$ \\
\hline Ukraina & & $\sqrt{ }$ & $\sqrt{ }$ & $\sqrt{ }$ & $\sqrt{ }$ & $\sqrt{ }$ \\
\hline Yunani & $\sqrt{ }$ & $\sqrt{ }$ & $\sqrt{ }$ & $\sqrt{ }$ & $\sqrt{ }$ & $\sqrt{ }$ \\
\hline Total & 17 & 35 & 45 & 39 & 34 & 39 \\
\hline
\end{tabular}

keamanan nasional AS diidentifikasi melalui dokumen-dokumen strategis yang dikeluarkan setiap periode pemerintahan. Dokumen strategis tersebut terutama berupa: National Security Strategy ${ }^{19}$ dan Quadrennial Defense Review Report ${ }^{20}$, serta kebijakan-kebijakan strategis lainnya yang mencerminkan kepentingan keamanan nasional AS.

Identifikasi Kepentingan Keamanan Nasional AS difokuskan pada kepentingan keamanan nasional dalam batasan tradisional. Secara tradisional, security dapat dipahami sebagai: "the security of the state (national security) threatened by the military power of other states and defended by the military power of the state itself."

Kemudian menurut Stephen Walt: "security studies may be defined as the study of the threat, use, and control of military force. It explores the conditions that make the use of force more likely, the ways that the use of force affects individuals, states, and societies, and the specific policies that states adopt in order to prepare for, prevent, or engage in war." ${ }^{22}$ Atau menurut Buzan: "military security concerns the two-level interplay of the armed offensive and defensive capabilities of states, and states perception of each other's intentions". ${ }^{23}$ Berdasarkan batasan-batasan tersebut, identifikasi atas kepentingan keamanan nasional AS dapat dibagi menjadi tiga unsur, yaitu: sumber-sumber yang dianggap sebagai ancaman dan tantangan pertahanan dan keamanan bagi AS; kebijakan-kebijakan pertahanan untuk mencapai tujuan nasional dan untuk menghadapi ancaman dan tantangan; serta kondisi lainnya yang memungkinkan AS untuk menggunakan kekuatan militer.

ANCAMAN DAN TANTANGAN KEAMANAN AS Berakhirnya Perang Dingin menyebabkan terjadinya perubahan 
fundamental atas lingkungan keamanan internasional dan kepentingan keamanan nasional AS. Lingkungan internasional semakin dinamis dan sumber ancaman semakin tidak pasti. Hubungan yang erat di berbagai bidang tercipta antara AS dan negara-negara yang sebelumnya merupakan musuh AS, sementara tetap berlawanan dalam isu-isu tertentu. AS tidak lagi menghadapi ancaman dari negara dengan kekuatan militer konvensional skala besar dan potensi terjadinya perang nuklir sebagaimana yang berlangsung selama Perang Dingin. Runtuhnya Uni Soviet menempatkan AS sebagai negara dengan kekuatan militer terbesar. Tidak terdapat global peer competitor yang mampu menandingi kekuatan militer AS jika AS mengerahkan keseluruhan potensi kekuatan nasionalnya. Tidak terdapatnya kekuatan militer konvensional yang mampu menandingi AS ditunjukkan oleh trend belanja pertahanan dunia pasca Perang Dingin (Lihat Bagan 1 dan 2). Data statistik ini dapat menunjukkan kapabilitas dan komitmen AS untuk menggunakan kekuatan militernya guna mendukung pencapaian tujuan nasional. Meskipun demikian terdapat potensi munculnya kekuatan regional seperti China dan Russia.

Ancaman militer yang dihadapi AS pasca Perang Dingin atau dalam periode 1994-2005 bukan berupa kekuatan militer konvensional skala besar yang mengancam homeland AS, melainkan berupa rogue states yang mengancam kepentingan vital AS jauh dari homeland AS. Negara-negara tersebut memiliki kekuatan militer yang cukup memadai untuk mengancam negara tetangganya; mengancam keamanan dan kepentingan AS beserta sekutu dan sahabat; dan mampu merusak perimbangan kekuatan dan stabilitas kawasan di mana AS memiliki kepentingan vital. AS menekankan sumber ancaman dari rogue states yang berusaha memperoleh dan mengembangkan senjata pemusnah massal beserta alat peluncurnya, dan yang berusaha memperoleh advanced weapons untuk meningkatkan kapabilitas militernya, serta menggunakan cara-cara asimetrik untuk menghadapi keunggulan kekuatan militer konvensional AS. ${ }^{24}$ Meskipun kemungkinan terjadinya paling kecil, perang

\section{Bagan 1 \\ 5 Negara Belanja Militer Terbesar Dunia: 1994-2003 (dalam juta \$)}

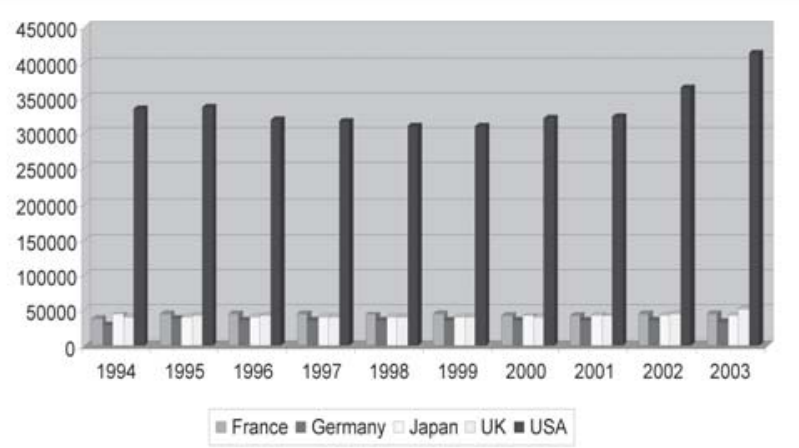

Sumber: diolah dari SIPRI Yearbook: Armament, Disarmament and International Security 2005 (London: Oxford University Press, 2005).

\section{Bagan 2}

5 Negara Belanja Militer Terbesar Dunia: 2004 (dalam miliar \$)

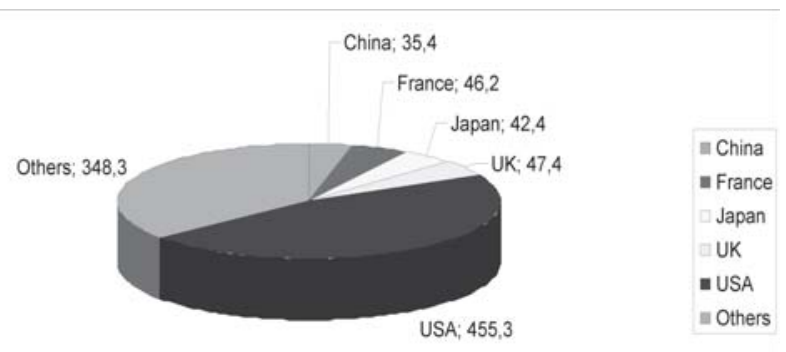

Sumber: diolah dari SIPRI Yearbook: Armament, Disarmament and International Security 2005 (London: Oxford University Press, 2005).

nuklir merupakan merupakan spektrum operasional tertinggi yang harus dipenuhi kekuatan militer AS. ${ }^{25}$

Dengan demikian, ancaman militer yang paling nyata dan harus dihadapi AS dalam jangka pendek adalah ancaman dari rogue states yang berupaya memperoleh senjata pemusnah masal dan sistem peluncurnya. Saat ini terdapat 32 negara yang memiliki misil balistik. Negara yang memiliki WMD biasanya berupaya membeli atau mengembangkan misil balistik untuk meluncurkan senjata tersebut ke target musuh. Delapan negara yang memiliki senjata nuklir, yaitu: AS, Inggris, Russia, China, Perancis, 
Tabel 2

Kapabilitas Misil Balistik Iran

\begin{tabular}{|c|c|c|c|c|}
\hline MISSILE & $\begin{array}{l}\text { RANGE } \\
(\mathrm{KM})\end{array}$ & $\begin{array}{l}\text { PAYLOAD } \\
(K G)\end{array}$ & $\begin{array}{l}\text { ESTIMATED } \\
\text { NUMBERS }\end{array}$ & STATUS \\
\hline $\begin{array}{l}\text { CSS-8 (M- } \\
7 / 8610)\end{array}$ & 150 & 190 & 200 & In Service \\
\hline CSS-6 (M-9) & 600 & 500 & & Possible \\
\hline $\begin{array}{l}\text { CSS-7 (M-11) } \\
\text { variant }\end{array}$ & 300 & 500 & & $\begin{array}{l}\text { Possible } \\
\text { Development }\end{array}$ \\
\hline Mushak-120 & 130 & $500 / 190$ & & In Service \\
\hline Mushak-160 & 160 & 190 & & In service \\
\hline Mushak-200 & 200 & 500 & & In development \\
\hline NP-110 & 170 & & & $\begin{array}{l}\text { In development with } \\
\text { chinese help }\end{array}$ \\
\hline $\begin{array}{l}\text { Shahab- } \\
\text { 3/Nodong variant }\end{array}$ & $1,300-1,500$ & $\begin{array}{l}750 / \\
800-1,200\end{array}$ & 20 & $\begin{array}{l}\text { Tested } 2004 \text { similar } \\
\text { to Nodong }\end{array}$ \\
\hline Shahab-4 & $\begin{array}{l}2,000-2,500 \\
\text { (or 4,000) }\end{array}$ & 1,000 & & $\begin{array}{l}\text { Possibly in } \\
\text { development }\end{array}$ \\
\hline Shahab-5 & 10,000 & & & $\begin{array}{l}\text { Possibly in } \\
\text { development }\end{array}$ \\
\hline SS-1 Scud-B & 300 & 1,000 & 200 & In service \\
\hline $\begin{array}{l}\text { Iran } 7000 \\
\text { (Scud C variant) }\end{array}$ & $600 / 700$ & 500 & 100 & In service \\
\hline Zelzal 1 & $100-150$ & & & In production \\
\hline Zelzal 2 & $350-400$ & & & In production \\
\hline Zelzal 3 & $1,000-1,500$ & & & In development \\
\hline $\begin{array}{l}\text { Two unnamed } \\
\text { programs }\end{array}$ & $5,500-10,000$ & 750 & & $\begin{array}{l}\text { In development, } \\
\text { unconfirmed }\end{array}$ \\
\hline
\end{tabular}

Sumber: diolah dari Andrew Feickert, Missile Survey: Ballistic and Cruise Missiles of Selected Foreign Countries, Congressional Research Service, 2005

Tabel 3

Kapabilitas Misil Balistik Korea Utara

\begin{tabular}{lllll}
\hline MISSILE & $\begin{array}{l}\text { RANGE } \\
(\mathrm{KM})\end{array}$ & $\begin{array}{l}\text { PAYLOAD } \\
(\mathrm{KG})\end{array}$ & $\begin{array}{l}\text { ESTIMATED } \\
\text { NUMBERS }\end{array}$ & STATUS \\
\hline Scud-B variant & 300 & 1,000 & 100 & In service \\
Scud-C & 500 & 700 & 100 & In service \\
Nodong & $1,000-1,300$ & 1,000 & & In service \\
Taepo Dong-1 & $1,500-2,000$ & 1,000 & & Tested in 1998 \\
Taepo Dong-2 & $4,000-6,000$ & & & In development \\
SS-N-6 variant & $3,000-3,600$ & 680 & $<10$ & In development \\
& & & & Possibly in \\
Taepo Dong $X$ & & & & development
\end{tabular}


India, Pakistan, dan Israel, juga memiliki misil balistik operasional. Hanya delapan negara ini, serta Iran dan Korea Utara yang telah memproduksi atau menguji coba misil dengan jangkauan lebih dari $1,000 \mathrm{~km}$. Sebelum Operation Iraqi Freedom, AS meyakini bahwa Iraq juga memiliki misil yang mampu mengancam keamanan sekutu dan pasukan AS yang berada di Teluk Persia. Jadi, rogue states yang dianggap sebagai sumber ancaman bagi kepentingan keamanan nasional AS adalah Irak, Iran, dan Korea Utara (Lihat Tabel 2 dan 3). ${ }^{26}$

\section{KEBIJAKAN PENGGUNAAN KEKUATAN MILITER AS}

Dalam lingkungan keamanan internasional yang berkembang pasca Perang Dingin, dengan berbagai tantangan dan ancaman yang dihadapi, serta dengan berbagai keunggulan dan kesempatan yang dimiliki AS, militer digunakan untuk mendukung pencapaian tujuan nasional. Bersama elemen kekuatan nasional lainnya, militer AS mengerahkan segala kemampuannya untuk mencapai tujuan tersebut sesuai dengan prioritas masing-masing periode pemerintahan.

Kekuatan militer AS digunakan dalam berbagai bentuk terutama preventive, defensive, dan offensive (defeating). Overseas presence baik dalam masa damai maupun krisis merupakan wujud penggunaan militer dengan tujuan preventive. Tindakan semacam ini dapat berupa: pangkalan militer permanen di luar negeri, penempatan basis perlengkapan dan logistik di luar negeri, gelar pasukan rotasional, pelatihan dan gelar pasukan bersama sekutu dan sahabat AS, operasi kemanusiaan, dan sebagainya. Tindakan defensive dapat berupa perlindungan homeland yang merupakan fungsi utama kekuatan militer AS. Meningkatnya ancaman misil balistik jarak jauh yang mampu menjangkau teritori AS menuntut penggelaran sistem pertahanan misil balistik yang efektif. Sistem pertahanan misil balistik merupakan salah satu wujud fungsi defensive kekuatan militer AS. Gelar sistem pertahanan misil yang efektif dapat pula berfungsi preventive, karena dapat mencegah musuh melakukan serangan misil karena menyadari tindakan mereka tidak akan mencapai tujuan. Bentuk penggunaan defensive militer dapat pula berupa dukungan militer terhadap departemen homeland security untuk menghadapi ancaman terorisme terhadap keamanan dan keselamatan warga, infrastruktur, serta nilai-nilai dasar AS. Selain itu, AS juga berkomitmen menggunakan kekuatan militernya untuk mengalahkan musuh (defeating/offensive) baik secara multilateral maupun unilateral, jika tujuan AS atau kepentingan vital AS terancam. Bahkan, pada pemerintahan Bush, dimungkinkan penggunaan kekuatan militer AS untuk mengalahkan musuh sebelum musuh memperoleh kapabilitas untuk mengancam keamanan nasional AS (preemptive strike). ${ }^{27}$

\section{KEBIJAKAN PENGEMBANGAN KEKUATAN MILITER AS}

Selama periode 1994-2005, pengembangan kekuatan militer AS diarahkan agar mampu menghadapi berbagai ancaman dan tantangan jangka pendek, serta siap menghadapi ancaman dan tantangan masa depan. Untuk menghadapi tantangan dan ancaman jangka pendek, militer AS berupaya mempertahankan dan meningkatkan kapabilitasnya untuk beroperasi di berbagai medan dan dalam berbagai bentuk. Dengan kata lain, AS membutuhkan kapabilitas operasi full-spectrum. Yaitu, militer yang mampu bertransisi dari aktivitas masa damai, menjadi deterrence krisis, sampai dengan operasi di medan perang besar (major theater war). Sedangkan untuk mampu tetap mendominasi operasi full-spectrum di masa depan, militer AS melakukan transformasi untuk memperoleh kemampuan operasi gabungan yang diarahkan oleh Joint Vision 2020. Berdasarkan JV 2020 yang mengandalkan superioritas informasi dan empat konsep operasional baru, yaitu: dominant maneuver, precision engagement, full-dimensional protection, dan focused logistic, maka militer AS sangat membutuhkan teknologi maju khususnya teknologi informasi yang mampu meningkatkan kapabilitas C4ISR militer AS. ${ }^{28}$

\section{PROGRAM SISTEM PERTAHANAN MISIL BALISTIK AS}

Berkaitan dengan ancaman jangka pendek yang mungkin dihadapi AS, kapabilitas yang paling dibutuhkan AS untuk itu adalah sistem pertahanan 
misil balistik untuk menghadapi ancaman kekuatan misil balistik dan senjata pemusnah masal rogue states.

Kebutuhan untuk mengembangkan dan menggelar sistem pertahanan yang efektif untuk menghadapi ancaman misil jarak dekat dan jauh sudah menjadi kepentingan keamanan nasional AS sejak 1960an. Upaya untuk membangun sistem ini menghadapi tantangan teknis dan kontroversial secara politis. Sekitar \$100 milyar telah dikeluarkan sejak pertengahan 1980an. ${ }^{29}$

Pemerintahan Clinton merestrukturisasi program BMD menyesuaikan dengan the 1993 Bottom-Up Review. Pemerintahan Clinton menekankan penggelaran sistem pertahanan misil untuk ancaman misil jarak dekat. Program pertahanan misil didasarkan pada penilaian bahwa sudah terdapat ancaman misil balistik pada tingkat regional, dan ancaman misil balistik terhadap AS hanya akan muncul di masa depan. DOD menetapkan bahwa program ini harus tetap mematuhi the 1972 ABM Treaty. Pada 1995 dikeluarkan The Missile Defense Act of 1995, yang isinya berupa kebijakan AS untuk:

(1) develop as soon as possible affordable and operationally effective theater missile defenses; (2) develop for deployment a multiple-site national missile defense system that is affordable and operationally effective against limited, accidental, and unauthorized ballistic missile attacks on the United States, and which can be augmented over time as the threat changes to provide a layered defense against limited, accidental, or unauthorized ballistic missile threats; (3) initiate negotiations with Russia as necessary to provide for the national defense systems envisioned by the act; and (4) consider, if those negotiations fail, the option of withdrawing from the ABM treaty. ${ }^{30}$

Pemerintahan Clinton menyesuaikan langkahnya dan mengadopsi strategi baru bagi pertahanan misil nasional. Pada 1996, pemerintahan Clinton mengadopsi strategi $3+3$ sebagai pedoman pengembangan dan penggelaran. Dengan strategi ini, AS akan mengembangkan sistem pertahanan misil untuk mempertahankan AS dari serangan sejumlah kecil misil balistik jarak jauh yang diluncurkan oleh hostile nations, atau, dari peluncuran aksidental atau unauthorized oleh Russia atau Cina. Strategi tersebut menginginkan pengembangan teknologi dalam tiga tahun pertama (1997-2000), dilanjutkan dengan keputusan penggelaran pada tahun 2000 jika dimungkinkan secara teknologi dan dibutuhkan karena ancaman. Jika keputusan penggelaran telah dibuat, maka penggelaran akan dilakukan dalam periode tiga tahun kedua (2000-2003). Pengembangan dan penggelaran dilakukan dengan pembatasan dari ABM treaty. Akhirnya pada September 2000, presiden Clinton memutuskan untuk tidak menggelar sistem pertahanan misil saat itu. Ia menyatakan bahwa belum cukup yakin dengan teknologi dan efektifitas operasional keseluruhan sistem NMD untuk menuju penggelaran. ${ }^{31}$

Bush memasuki pemerintahan dengan upaya untuk penggelaran pertahanan misil balistik sebagai salah satu tujuan keamanan nasional. Pemerintahan Bush meningkatkan pendanaan untuk program pertahanan misil, dan memutuskan untuk mundur dari the 1972 ABM Treaty. ${ }^{32}$

Pada Januari 2002, Sekretaris Pertahanan, Donald Rumsfeld mengeluarkan memorandum mengenai Program Pertahanan Misil DOD. Ia menyebutkan empat prioritas utama pertahanan misil, yaitu: (a) to defend the USA, deployed forces, allies and friends; (b) to employ a Ballistic Missile Defense System (BMDS) that layers defenses to intercept missiles in all phases of their flight; (c) to enable services to field elements of the overall BMDS as soon as practicable; (d) to develop and test technologies and improve the effectiveness of deployed capability by inserting new technologies as they become available or when the threat warrants an accelerated capability. Memorandum tersebut mengarahkan DOD untuk mengembangkan system pertahanan misil jauh melebihi yang direncanakan oleh Pemerintahan Clinton.

Pada 2002, Presiden mengumumkan keputusannya untuk menggelar sistem pertahanan misil balistik terbatas untuk menghadapi misil jarak jauh pada 2004. Pada 17 desember 2002, Missile Defense Agency (MDA, sebelum Januari 2002 dikenal sebagai the 
Tabel 4

Japan-US Joint Research Projects

\begin{tabular}{|c|c|c|c|}
\hline PROJECT & SUMMARY & $\begin{array}{l}\text { TIME OF } \\
\text { CONCLUSION }\end{array}$ & $\begin{array}{l}\text { TIME OF } \\
\text { COMPLETION }\end{array}$ \\
\hline $\begin{array}{l}\text { Ducted Rocket } \\
\text { Engine }\end{array}$ & $\begin{array}{l}\text { Research into basic technology for the } \\
\text { secondary combustion of solid rocket fuel } \\
\text { through the injection of air from external } \\
\text { source }\end{array}$ & September 1992 & $\begin{array}{l}\text { January } \\
1999\end{array}$ \\
\hline $\begin{array}{l}\text { Advanced Steel } \\
\text { Technology }\end{array}$ & $\begin{array}{l}\text { Research into basic technology for the } \\
\text { welding of extra high-strength steel used in } \\
\text { the pressure hulls of submarines, etc. }\end{array}$ & October 1995 & $\begin{array}{l}\text { January } \\
2002\end{array}$ \\
\hline $\begin{array}{l}\text { Fighting Vehicle } \\
\text { Propulsion } \\
\text { Technology } \\
\text { Using Ceramic } \\
\text { Materials }\end{array}$ & $\begin{array}{l}\text { Research into basic technology related to } \\
\text { diesel engines using ceramic materials }\end{array}$ & October 1995 & $\begin{array}{l}\text { October } \\
2002\end{array}$ \\
\hline $\begin{array}{l}\text { Eye-Safe Laser } \\
\text { Radar }\end{array}$ & $\begin{array}{l}\text { Research into basic technology related to } \\
\text { LIDAR systems using eye-safe frequencies }\end{array}$ & September 1996 & $\begin{array}{l}\text { September } \\
2001\end{array}$ \\
\hline Ejection Seat & $\begin{array}{l}\text { Modification work to supplement combat } \\
\text { aircraft ejector seats with pilot-restraint } \\
\text { devices and seat-stabilizing equipment }\end{array}$ & March 1998 & March 2003 \\
\hline $\begin{array}{l}\text { Advance Hybrid } \\
\text { Propulsion } \\
\text { Technology }\end{array}$ & $\begin{array}{l}\text { Research into basic technology related to } \\
\text { thrust-controllable propulsion devices made } \\
\text { up of solid fuel and liquid oxidizers }\end{array}$ & May 1998 & Ongoing \\
\hline $\begin{array}{l}\text { Shallow Water } \\
\text { Acoustic } \\
\text { Technology }\end{array}$ & $\begin{array}{l}\text { Research related to the analysis of the } \\
\text { characteristics of transmittance of sound } \\
\text { waves in shallow sea regions, and the } \\
\text { reflection of sound waves on the seabed }\end{array}$ & June 1999 & $\begin{array}{l}\text { February } \\
2003\end{array}$ \\
\hline $\begin{array}{l}\text { Ballistic Missile } \\
\text { Defense } \\
\text { Technology }\end{array}$ & $\begin{array}{l}\text { Research related to the Navy's Theater Wide } \\
\text { Defense System's (current Sea-based } \\
\text { Midcourse Defense System) four principal } \\
\text { missile components (infrared seeker, kinetic } \\
\text { warhead, second stage rocket motor and } \\
\text { nose cone) }\end{array}$ & August 1999 & Ongoing \\
\hline $\begin{array}{l}\text { Low } \\
\text { Vulnerability } \\
\text { Gun Propellant } \\
\text { for Field } \\
\text { Artillery }\end{array}$ & $\begin{array}{l}\text { Research related to the development of } \\
\text { gunpowder that avoids unintentional } \\
\text { secondary explosions of the gunpowder at } \\
\text { the time of bombing }\end{array}$ & March 2000 & $\begin{array}{l}\text { January } \\
2004\end{array}$ \\
\hline $\begin{array}{l}\text { Avionics } \\
\text { Aboard the } \\
\text { Follow-on } \\
\text { Aircraft to the } \\
\text { P-3C }\end{array}$ & $\begin{array}{l}\text { Research into onboard avionics of the } \\
\text { MSDF's next } P-3 C \text { fixed-wing maritime } \\
\text { patrol aircraft (P-X) and the US Navy's } \\
\text { future Multi-purpose Maritime Aircraft } \\
(M M A) \text { for better interoperability }\end{array}$ & March 2002 & Ongoing \\
\hline Software Radio & $\begin{array}{l}\text { Research into basic technologies of } \\
\text { software radio, which enables primary radio } \\
\text { functions through software }\end{array}$ & March 2002 & Ongoing \\
\hline
\end{tabular}


Ballistic Missile Defense Organization) mengumumkan bahwa telah diperintahkan oleh Bush untuk mulai menggelar, pada 2004-2005, sistem pertahanan misil awal untuk menghadapi ancaman misil balistik jangka pendek; terhadap homeland AS, deployed forces, sekutu dan sahabat. Pengumuman tersebut merupakan pertama kali pemerintahan Bush menetapkan kapabilitas BMD untuk melindungi teritori AS dan berkomitmen pada satu tanggal penggelaran yang spesifik. ${ }^{33}$

\section{PROLIFERASI DUAL-USE TECHNOLOGY JEPANG}

Gambaran proliferasi DUT Jepang dapat diperoleh dengan menguraikan sistem export control nasional yang diterapkan Jepang. Kathleen Miller dan Caroline Brooks menjelaskan bahwa: "a national export control system allows countries to make the decisions whether or not to export certain defense-related items to particular destinations". ${ }^{34}$

Pengaturan ekspor persenjataan Jepang diatur berdasarkan kebijakan the Three Principles on Arms Export yang dikeluarkan oleh PM Eisaku Sato pada 21 April 1967, dan dipertegas PM Takeo Miki pada Februari 1976 yang melarang ekspor persenjataan dan teknologi militer ke seluruh negara. Di samping itu, the 1983 Exchange of Notes, pemerintah Jepang mengizinkan transfer teknologi militer kepada AS sebagai pengecualian. Sedangkan ekspor dual-use technology Jepang diatur berdasarkan FEFTCL (the Foreign Exchange and Foreign Trade Control Law), dan didukung berbagai ketetapan lainnya baik berupa Cabinet Order, Ministerial Ordinance, maupun Notifications.

Pemerintah Jepang mulai melaksanakan sistem pengendalian ekspor sejak 1949 berdasarkan FEFTCL. Namun demikian, hukum Jepang secara formal mengizinkan pemerintah untuk membentuk kontrol hanya untuk memenuhi kepentingan ekonomi Jepang, yaitu untuk tujuan balance of payment dan stabilisasi nilai tukar, daripada untuk kepentingan keamanan nasional. ${ }^{35}$ Pada 1980, pemerintah mengubah hukum dan mengumumkan regulasi baru untuk mencakup 'security' sebagai pertimbangan pengendalian ekspor teknologi. Kemudian setelah kasus Toshiba, pemerintah memodifikasi hukum dan regulasi untuk menambahkan 'international peace and security' sebagai pertimbangan pengendalian ekspor. Sejak 1987, Jepang mulai mereformasi sistem pengendalian ekspornya secara radikal. Selain kasus Toshiba, beberapa peristiwa lain juga turut mempengaruhi sistem pengendalian ekspor Jepang, antara lain: peristiwa Hiroshima dan Nagasaki yang mengakibatkan menyerahnya Jepang pada 1945, pengungkapan program senjata biologi dan kimia Jepang, uji coba nuklir oleh Perancis dan China pada 1990an, serangan gas di Tokyo pada Maret 1995, penyelundupan sodium fluoride dan hydrofluoric acid-yang merupakan bahan dasar sarin-menuju Korea Utara. Peristiwa tersebut mendorong Jepang untuk membangun kebijakankebijakan nonproliferasi. Pemerintah Jepang meningkatkan perhatiannya atas persoalan proliferasi senjata nuklir, kimia, dan biologi (senjata pemusnah masal). Hal ini mendorong dilakukannya penyesuaian sistem pengendalian ekspor sesuai dengan lingkungan internasional pasca Perang Dingin yang diwarnai dengan persoalan proliferasi senjata pemusnah masal. ${ }^{36}$ Meskipun COCOM telah dibubarkan, Jepang tetap mengadopsi aturan-aturan rezim pengendalian ekspor yang lainnya untuk membangun sistem pengendalian ekspor nasionalnya.

Perundangan pengendalian ekspor terkuat sekalipun akan menjadi lemah tanpa implementasi kebijakan. Berdasarkan legislasi dan regulasinya, dual use technology Jepang hanya dapat dimanfaatkan secara legal oleh militer AS. Eksportir Jepang diizinkan melakukan transfer teknologi menuju negara selain AS hanya untuk kepentingan-kepentingan komersil sipil. Implementasi sistem pengendalian ekspor yang lemah akan memungkinkan terjadinya penyimpanganpenyimpangan pemanfaatan dual-use technology Jepang

\section{TRANSFER TEKNOLOGI MILITER KE AS}

Sejak kebijakan pengecualian 1983, Jepang telah menetapkan untuk menyediakan 13 item teknologi militer Jepang kepada AS, mulai dari teknologi portable surface-to-air missile (SAM) untuk kapal laut AS sampai 
penelitian teknologi persenjataan berkaitan dengan penelitian teknis bersama (joint technical research) atas pertahanan misil balistik. Sejauh ini, kedua negara telah menghasilkan 11 perjanjian proyek penelitian bersama. Diantara proyek kerjasama tesebut, tujuh proyek sudah diselesaikan (Lihat Tabel 3). Pada Mei 2003, pemerintah kedua negara menghasilkan perjanjian untuk the Engineers and Scientists Exchange Program (ESEP). Kemudian pada Agustus 2003, Jepang mengirimkan tenaga ahli di bidang teknologi laser ke AS. Kerjasama perlengkapan dan teknologi militer antara AS-Jepang sangat berarti untuk mengurangi biaya dan resiko penelitian dan pengembangan $(R \& D)$, dan kedua negara telah memeriksa kemungkinan untuk memperluas proyek penelitian bersama mereka. ${ }^{37}$

Namun tidak dapat dipungkiri bahwa AS mengalami kesulitan untuk memperoleh dukungan Jepang untuk membangun sistem pertahanan misilnya, baik dalam proyek sistem Theater Missile Defense (TMD) yang diprogramkan pemerintahan Clinton, maupun proyek National Missile Defense (NMD) yang diprogramkan oleh pemerintahan Bush.

\section{PENYIMPANGAN TRANSFER DUT JEPANG}

Sejumlah laporan penyimpangan ekspor menunjukkan bahwa masih terdapat kelemahan pada sistem pengendalian ekspor nasional Jepang. Penyimpangan tersebut antara lain: pada akhir 2005, polisi Jepang merazia Yamaha Motor Co. Ltd. karena dicurigai berupaya melakukan ekspor ilegal ke Cina berupa helikopter agrikultur yang dapat dialihkan untuk tujuan militer; sebuah perusahaan pembuat mesin di Jepang, dicurigai melakukan ekspor ilegal ke Iran perlengkapan yang dapat digunakan untuk tujuan militer pada 1999. Seishin Enterprise Co. mengekspor alat industri yang juga dapat digunakan untuk menghasilkan bahan bakar solid untuk misil dalam sejumlah kesempatan antara 1987 dan 2000; pada tahun 2003, polisi Jepang menangkap 5 manajer dealer mobil bekas karena melakukan ekspor ilegal ke Korea Utara. Mereka mengekspor trailer yang dapat diubah menjadi peluncur mobile misil balistik; dalam investigasi IAEA ketika menyelidiki transfer teknologi nuklir ke Libya, Iran, dan negara lainnya terungkap bahwa terdapat komponen centrifuge untuk pengayaan uranium yang dibeli dari perusahaan Jepang melalui pasar gelap oleh Abdul Qadeer Kahn. Kondisi ini membuka kemungkinan penyimpangan pemanfaatan dual-use technology Jepang untuk kepentingan yang dapat mengancam keamanan nasional AS.

\section{KESIMPULAN}

Dapat disimpulkan bahwa penolakan kongres AS atas permohonan Jepang untuk membeli jet tempur F22 Raptor disebabkan oleh faktor-faktor berikut, yaitu: pertama, adanya kecenderungan kelompok industri Jepang untuk melakukan pengalihan teknologi militer menjadi teknologi sipil-komersil; kedua, kekhawatiran AS pada kemampuan Jepang untuk menyerap teknologi militer AS; ketiga, adanya sejumlah pelanggaran rezim pengendalian ekspor oleh Jepang pada masa Perang Dingin; keempat, lemahnya rezim pengendalian ekspor pada level multilateral; kelima, bahwa AS menghadapi ancaman rogue states yang mengembangkan WMD menggunakan DUT sehingga menjadi kepentingan AS untuk menghambat proliferasi DUT; dan keenam, masih terdapatnya celah pada sistem pengendalian ekspor nasional Jepang yang memungkinkan terjadinya penyimpangan transfer DUT.

Friksi yang terjadi selama perundingan proyek FSX, serta masih sulitnya bagi AS untuk memperoleh teknologi militer Jepang untuk membangun sistem pertahanan misil balistik sementara program tersebut merupakan kebutuhan teratas AS untuk menghadapi ancaman jangka pendek, merupakan faktor yang juga akan mempersulit Jepang untuk memperoleh izin pembelian F-22 Raptor dari kongres AS. Dengan melihat pada pengalaman proyek FSX, rencana Jepang untuk membangun sendiri prototipe jet tempur tidak akan memperlunak penolakan kongres AS. Rencana tersebut justru dapat menimbulkan kembali kekhawatiran AS akan kemungkinan Jepang mengungguli kapabilitas teknologi militer AS. 


\section{CATATAN AKHIR}

Andrew Latham (1999), Re-Imagining Warfare: The 'Revolution in Military Affairs', dalam Craig A. Snyder (ed.), Contemporary Security and Strategy, London: MacMillan Press, hlm. 211-213.

2 Ibid.,

3 "Japan Still Smulling All Options for Next Fighter Jet, But Pushing for Restricted US Model", (2007), International Herald Tribune, July 26, diakses dari http://www.iht.com/articles/ap/2007/07/26/asia/ASGEN-Japan-US-Fighters.php

4 Daniel Barclay (2004), The Technology of Japan, MURJ, Volume 11, hlm. 13.

5 Sheila A. Smith (1999), The Evolution of Military Cooperation in the US-Japan Alliance, di dalam Michael J. Green, The US-Japan Alliance: Past, Present, and Future, Council on Foreign Relations Press, hal. 74

6 Spin-off adalah penerapan teknologi militer pada sektor komersil, sedangkan spin-on adalah penerapan teknologi komersil sipil pada sektor militer.

7 Selama Perang Dingin negara-negara NATO, serta Jepang dan Australia tergabung dalam COCOM. COCOM berupaya untuk membatasi ekspor item-item strategis pada Uni Soviet, Negaranegara Eropa Timur dan RRC.

8 Bates Gill, Kensuke Ebata, \& Matthew Stephenson (2000), Japan's Export Control Initiatives: Meeting New Challenges, The Nonproliferation Review, Fall 1996, hlm. 34, lihat juga Cecil H. Uyehara, The US-Japan Science and Technology Agreement: a drama in five acts, Ashgate Publishing Ltd., hlm. 100.

9 Glenn Schweitzer (1994), A Conceptual Approach to Addressing Dual-Use Technologies: A Framework for U.S.-Russian Dialogue, dalam National Research Council, Dual-Use Technologies and Export Control in the Post-Cold War Era, Washington, DC: National Academy Press,, hlm. 125.

10 Roger Cliff (2001), The Military Potential of China's Commercial Technology, Santa Monica: RAND, hlm. 11.

11 Yang dimaksud dengan Strategically Dangerous Armaments (SDAs) antara lain: senjata pemusnah massal (seperti senjata nuklir, kimia, and biologis), sistem untuk peluncurannya/delivery system (termasuk ballistic missiles dan advanced strike aircraft), dan senjata konvensional modern seperti precision-guided munitions (PGMs). Lihat dalam National Research Council, Op.Cit., hlm.5.

12 Bates Gill, Kensuke Ebata, \& Matthew Stephenson, Op. Cit. ,, hlm. 30.

13 Disebut sebagai Zangger Committee sesuai dengan nama ketua pertama komite ini, yaitu: Prof. Claude Zangger. Komite ini dikenal juga sebagai the Nuclear Exporters Committee.

14 Artikel III.2 menyatakan bahwa setiap negara yang terlibat dalam NPT tidak boleh mengekspor, secara langsung atau tidak langsung, material dan perlengkapan nuklir kepada negara non-nuklir (nonnuclear weapon states) yang tidak terlibat NPT, kecuali jika di bawah pengawasan International Atomic Energy Agency (IAEA)

15 Jing-dong Yuan (1994), Nonproliferation Export Controls in the 1990s: Multilateral Regimes, National Policies, and Implications for Canada's Defence Industry, Canada: Centre for International Relations, hlm. 9.

16 Objectives of the Group, diakses dari http:// www.australiagroup.net/en/agobj.htm tanggal 7 Januari 2006.
18 Diakses dari http://www.mtcr.info/english/objectives.html tanggal 8 Januari 2006.

19 NSS merupakan laporan yang disusun setiap pemerintahan atas permintaan the Goldwater-Nichols Act of 1986, untuk menyerahkan laporan pada Kongres yang menunjukkan sasaran komprehensif keamanan strategis bangsa.

20 QDR berisi eksaminasi fundamental dan komprehensif atas kebutuhan pertahanan AS: ancaman potensial, strategi, struktur kekuatan, postur kesiagaan, program modernisasi militer, infrastruktur pertahanan, dan elemen program pertahanan lainnya. QDR disusun atas permintaan the Military Force Structure Review Act.

21 David Mutimer (1999), "Beyond Strategy: Critical Thinking and the New Security Studies", dalam Craig A. Snyder (ed.), Contemporary Security and Strategy, London: MacMillan Press, hlm. 77.

22 Ibid.,

23 Barry Buzan (1991), People, State, and Fear: An Agenda for International Security Studies in the Post-Cold War Era, (New York: Harvester Wheatsheaf, hlm. 19-20.

24 Rizki Roza (2006), Implikasi Proliferasi Dual-Use Technology Jepang terhadap Kepentingan Keamanan Nasional AS Pasca COCOM (1994-2005), Jakarta: Tesis, Universitas Indonesia, hal. 82.

25 Sam J.Tangredi, Assessing New Missions, dalam Hans Binnendijk (ed.) (2002), Transforming America's Military, Washington, D.C: National University Press, 2002, hal. 3-12.

26 Jika mempersoalkan isu proliferasi WMD, ancaman paling besar berasal dari nation-states dengan program senjata nuklir rahasia. Iran, Irak, dan Korea Utara berada di bawah pengawasan masyarakat internasional atas upaya mereka untuk memperoleh WMD. Berdasarkan Stanford Database on Nuclear Smuggling, Theft, and Orphan Radiation Sources (DSTO), selama periode 19912002 ketiga negara merupakan tujuan utama penyelundupan nuklir, radioactive, dan material dual-use yang berkaitan dengan nuklir. Iran dan Irak sejumlah 10 kasus, dan Korea Utara pada 6 kasus. Lihat Lyudmila Zaitseva dan Kevin Hand, Nuclear Smuggling Chains: Suppliers, Intermediaries, and End-users, The American Behavioral Scientist, Vol. 46.

27 Rizki Roza, Op.Cit, hal. 93-94

28 Ibid., hal. 94-95

29 Steven A. Hildreth (2005), Ballistic Missile Defense: Historical Overview, CRS Report for Congress, 22 April, hlm. 1, diakses dari http://www.fas.org/sgp/crs/weapons/RS22120.pdf tanggal 20 Oktober 2006.

30 Ibid., hlm. 4.

31 Ibid., hlm. 4-5.

32 Ibid., hlm. 5.

33 SIPRI Yearbook: Armament, Disarmament and International Security 2003, London: Oxford University Press, 2005, hlm. 605609.

34 Kathleen Miller \& Caroline Brooks (2001), Export Control in the Framework Agreement Countries, British American Security Information Council, hlm. 8.

35 Dengan jaminan perlindungan militer AS, pemerintahan Jepang pascaperang menempatkan pertumbuhan ekonomi sebagai tujuan utamanya. Pemerintah Jepang berusaha untuk memanfaatkan ekspor sebagai mesin bagi kemakmuran ekonomi. Bahkan ketika 
Jepang bergabung dengan COCOM pada September 1952 pemerintah justru terlihat mengurangi hambatan perdagangannya dengan China. Richard T. Cupitt, Nonproliferation Export Contro/s In Japan. diakses dari http://www.uga.edu/cits/documents/html/ nat_eval_japan.htm., ; Jing-dong Yuan, Op.Cit., hlm. 37.

36 Richard T. Cupitt, Loc. Cit.,

37 Japan Defense Agency, Defense of Japan 2000. Japan: Urban Connections, 2001, hlm. 145-146.

\section{REFERENSI}

Binnendijk, Hans (ed.). (2002). Transforming America's Military. Washington, D.C: National University Press,

Barclay, Daniel (2004), The Technology of Japan, MURJ, Volume 11.

Buzan, Barry (1991). People, State \& Fear $2^{\text {nd }}$ Ed: An Agenda for International Security Studies in the Post-Cold War Era. New York: Harvester Wheatsheaf.

Cliff, Roger (2001). The Military Potential of China's Commercial Technology. Santa Monica: RAND. Cupitt, Richard T. Nonproliferation Export Contro/s In Japan. diakses dari http://www.uga.edu/cits/ documents/html/nat_eval japan.htm

Fukuyama, Francis \& Kongdan Oh (1993). The US-Japan Security Relationship After the Cold War. RAND.

Gill, Bates, Kensuke Ebata, \& Matthew Stephenson (1996). Japan's Export Control Initiatives: Meeting New Challenges. The Nonproliferation Review, Fall.

Goldblat (2002), Jozef. Arms Control: New Guide to Negotiations and Agreements. London: Sage Publication, 2002.

Green, Michael J. The US-Japan Alliance: Past, Present, and Future (1999). New York: Council on Foreign Relations Press.

Hildreth, Steven A (2005). Ballistic Missile Defense: Historical Overview. CRS Report for Congress, 22 April. Diakses dari http://www.fas.org/ crs/weapons/RS22120.pdf

Japan Defense Agency. Defense of Japan 2000 (2005). Japan: Urban Connections.

Levi, Michael A. \& Michael E. O'Hanlon (2005). The Future of Arms Control. Washington, D.C.: The Brookings Institution.

Miller, Kathleen \& Caroline Brooks (2001). Export Control in the Framework Agreement Countries. British American Security Information Council.

National Research Council (1994). Dual-Use Technologies and Export Control in the Post-Cold War Era. Washington, DC: National Academy Press.

SIPRI Yearbook 2005: Armaments, Disarmament and International Security (2005). London: Oxford University Press.

SIPRI Yearbook (2004): Armaments, Disarmament and International Security. London: Oxford University Press.

SIPRI Yearbook (2003): Armament, Disarmament and International Security. London: Oxford University Press.

SIPRI Yearbook (2002): Armament, Disarmament and International Security. London: Oxford University Press.

Snyder, Craig A (1999). Contemporary Security and Strategy. Great Britain: MacMillan Pess LTD.

Uyehara, Cecil H (2000). The US-Japan Science and Technology Agreement: a drama in five acts. Ashgate Publishing Ltd.

Yuan, Jing-dong (1994). Nonproliferation Export Controls in the 1990s: Multilateral Regimes, National Policies, and Implications for Canada's Defence Industry. Canada: Centre for International Relations.

http://www.australiagroup.net

http://www.mtcr.info

http://www.nuclearsuppliersgroup.org

http://www.wassenaar.org 